\title{
PENDIDIKAN AGAMA ISLAM BERWAWASAN LINGKUNGAN HIDUP
}

\author{
Oleh: \\ Siti Yumnah \\ Sekolah Tinggi Agama Islam Pancawahana Bangil, Indonesia \\ sitiyumnah30@gmail.com
}

\begin{abstract}
:
Actually, if we reflect and re-understand the verses of Al Qur'an, it has become clear that natural disasters and environmental crises are the result of human activity. Environmental damage has long been pointed out in Al Qur'an. In Islam's view, human beings are actually Allah's creatures assigned as caliphs, as regulators, and maintainers of this earth. But the grievous reality that is happening right now is that it is increasingly complex and leads to uncontrolled conditions with increasing world population growth that exceeds the natural productivity capacity of the earth. A large population is a potential for advancing the country, but if it is not balanced with an adequate level of understanding of ecology then it means disaster. Humans now have openly exploited the natural resources on earth and forced the earth to give more than what the earth produced according to its capacity. So this is where the role of Islamic education is needed as a reminder and bearer of good news to humans so that they are always obedient and obedient to Allah's commands to be able to be a caliph who is able to preserve the environment on earth along with other creatures.
\end{abstract}

Keywords: Pendidikan Agama Islam, Lingkungan Hidup, Islamic Religious Education, Environment

\section{A. Pendahuluan}

Pada abad ke-21, lingkungan sering kali dibicarakan dan menjadi topik yang diperhatikan, karena pada zaman ini lingkungan tidak hanya menjadi isu lokal, tapi juga termasuk dalam perbincangan isu global setelah demokrasi dan HAM. Adanya lingkungan memberikan pengaruh penting dalam kehidupan makhluk hidup.

Lingkungan sebagai bagian penting dari kehidupan manusia, tentunya menjadi kesatuan yang perlu untuk dijaga dan dilestarikan karena kerusakan lingkungan bisa menjadikan masalah besar bagi manusia. Saat ini kemusnahan lingkungan di dunia, terutama di Negara 
Indonesia telah mendapatkan atensi khusus. Adanya pemicu pemanasan global yang merusak ekosistem lingkungan, maka hal tersebut akan terjadi bencana alam seperti langkanya sumber mata air, kekeringan, banjir, tsunami, tanah longsor, ${ }^{1}$ dan bencana yang disebabkan oleh manusia seperti polusi udara, pencemaran air dan kebakaran hutan. Potensi kerusakan lingkungan perlu dihindari dengan adanya kesadaran manusia.

Pendidikan agama Islam termasuk mata pelajaran yang wajib terintegerasi dengan pemahaman lingkungan hidup. Mengingat agama Islam sangat berhubungan erat dengan lingkungan hidup. Erwati Aziz dalam bukunya Upaya melestarikan Lingkungan Melalui Pendidikan Agama Islam menyebutkan bahwa pendidikan agama Islam menjadi dasar dalam menjaga lingkungan hidup, sebagai patokan dan ujung tombak dalam pendidikan, tentunya pendidikan agama Islam berperan dalam memahami konsep peduli lingkungan. Pernyataan ini memberikan kesan bahwa pendidikan Islam dijadikan sebagai model dalam menjaga dan melestarikan lingkungan hidup.

Kemudian Erwati Aziz menambahkan bahwasanya pendidikan agama Islam kurang mendapat perhatian. Pendidikan agama Islam hanya sebuah doktrin dari sebuah ajaran. Hal ini kurang ada ada tindak implementasi nilai-nilai Islam yang terakomodir dengan lingkungan. Agar pembinaan dan pelestarian lingkungan perlu adanya kurikulum yang terintegrasi antara PLH dan PAI. ${ }^{2}$ Hal ini dilakukan agar ada kausalitas antara nilai-nilai Islam sebagai pedoman dalam menjadikan lingkungan sebagai bahan perenungan untuk menjadi manusia yang sempurna.

Dengan demikian, pendidikan sangat mempengaruhi pola berifikir manusia sekaligus dapat mengubah karakter manusia melalui pembiasaan sikap peduli lingkungan, oleh karena itu, setiap mata pelajaran harus memuat tentang pendidikan lingkungan hidup, khususnya pembelajaran pendidikan agama Islam.

\section{B. Definisi Pendidikan Agama Islam}

Sekilas tentang pengertian pendidikan agama Islam, sebenarnya sudah dibahas pada penjelasan terdahulu. Namun pada pembahasan kali ini, penulis memaparkan pengertian pendidikan agama Islam secara komplit dan komprehensif. Pada bagian ini, sebelum memaparkan

1 Pande Made Kutanegara, dkk, Membangun Masyarakat Indonesia Peduli Lingkungan, (Yogyakarta: UGM Press, 2014), 1.

2 Aziz Erwati, Pelestarian Lingkungan Melalui Pendidikan Agama Islam, (Yogyakarta: Pustaka Belajar, 2013), 12.

$326 \mid$ JURNAL LISAN AL-HAL 
pengertian pendidikan agama Islam, perlu adanya pembahasan tentang pengertian pendidikan terlebih dahulu, sebagai tolak ukur dalam mengetahui pengertian pendidikan agama Islam.

Beberapa pakar pendidikan, seperti Jhon Dewey yang menyebut bahwa pendidikan adalah sebuah proses pembentukan jati diri manusia yang memiliki kecakapan fundamental baik secara intelektual maupun emosional yang peduli terhadap lingkungan dan manusia disekitarnya. ${ }^{3}$ Kemudian Brown mengemukakan bahwa pendidikan merupakan sebuah proses pengawasan yang dilakukan secara sadar atas perubahanperubahan yang terjadi pada tingkah laku yang dimanifestasikan ke dalam diri pribadi masing-masing maupun ke dalam suatu kelompok. Dengan demikian, pendidikan pada intinya merupakan suatu proses bimbingan yang ditanamkan sejak manusia dilahirkan dan berlangsung sepanjang hayat. 4

Dari beberapa pengertian tersebut, pendidikan disepakati sebagai proses mendidik. Maksud dari proses mendidik adalah usaha sadar merubah peserta didik secara fisik maupun psikis dalam menghadapi persoalan-persoalan yang akan dialami. Melalui pendidikan, diharapkan manusia memiliki keintektualan dan keterampilan.

Sedangkan pengertian pendidikan agama Islam tentunya tidak jauh dari pengertian kata pendidikan, hanya saja yang perlu ditekankan dalam pendidikan agama Islam ialah aspek-aspek dan nilai-nilai yang terkandung dalam ajaran Islam. Seperti yang disampaikan oleh Zakiyah Daradjat, ia menafsirkan pendidikan Islam yakni pendidikan yang bernuansa nilainilai ajaran agama Islam, yang berupa bimbingan dan pendampingan terhadap anak didik agar nantinya setelah lulus dari pendidikannya ia dapat memahami, menghayati, dan mengamalkan ajaran-ajaran agama Islam yang telah diyakininya secara total, serta menjadikan ajaran agama Islam sebagai way of life demi menjaga keselamatan dan kesejahteraan hidup di dunia maupun akhirat kelak. ${ }^{5}$

Selain itu, pendidikan agama Islam didefinisikan oleh Naquib Al Athas sebagai usaha yang dilakukan oleh pendidik terhadap anak didik untuk pengenalan dan pengakuan tempat-tempat yang benar dari segala sesuatu di dalam tatanan penciptaan, sehiingga membimbing ke ararh pengenalan dan pengakuan akan tempat Tuhan yang tepat di dalam

${ }^{3}$ Ahmadi dan Uhbiyathi, Ilmu Pendidikan, (Jakarta: Rineka Cipta, 2007), 69.

${ }^{4}$ Ahmadi, Psikologi Pendidikan, (Jakarta: Rineka Cipta, 2004), 74.

5 Zakiah Darojat, Ilmu Pendidikan Islam, (Cet, ke 3, Jakarta: Bumi Aksara, 2008), 28. 
tatanan wujud dan kepribadian. ${ }^{6}$

Pengertian diatas sebagaimana pengetian pendidikan agama Islam yang diisimpulkan sebagai usaha sadar dan terencana untuk mengupayakan terbentuknya manusia yang bertaqwa kepada Allah SWT atas dasar nilai-nilai ajaran Islam, yang kemudian diimplementasikan dalam kehidupan sehari-hari.

\section{Lingkungan Hidup Dalam Pandangan Islam}

Membahas lingkungan tentu tidak akan terpisahkan dengan kehidupan, sehingga muncul istilah lingkungan hidup. Secara terpisah frase tersebut memiliki makna yang saling mendukung satu sama lain. Lingkungan adalah segala sesuatu yang ada disekitar yang mempengaruhi perkembangan dan tingkah laku makhluq hidup. ${ }^{7}$

Dalam Undang-undang Nomor 23 Tahun 1997, lingkungan diartikan sebagai kesatuan ruang dengan semua benda, daya, keadaan dan makhluk hidup termasuk manusia dan prilakunya yang mempengaruhi kelangsungan perikehidupan dan kesejahteraan manusia serta makhluk hidup lain. ${ }^{8}$ Sedangkan hidup dalam KBBI bermakna bergerak, ada, dan bekerja, seperti ungkapan "manusia itu hidup" maka manusia tersebut ada, mampu bergerak dan bekerja. Oleh karena itu hidup berarti mengalami kehidupan dalam keadaan atau dengan cara tertentu.

Dari dua kata tersebut jika digabungkan memiliki arti yang saling membutuhkan. Lingkungan Hidup diartikan sebagai segala sesuatu yang ada dilingkungan makhluk hidup yang dapat menyebabkan timbulnya perkembangan terhadap tingkah lakunya. oleh karena itu, Lingkungan hidup diartikan sebagai sistem kesatuan ruang dengan segala yang ada seperti benda, daya, keadaan yang menimbulkan prilaku yang mempengaruhi keberlangsungan kehidupan dan kesejahtreaan makhluk hidup. ${ }^{9}$ Pengertian seperti ini terdapat dalam QS. Al Baqarah ayat 164;

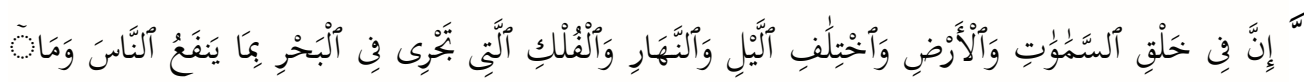

\footnotetext{
28.

7 Syukri Hamza, Pendidikan Lingkungan Hidup Sekelumit Wawasan Pengantar, (Bandung:Revika Aditama, 2013), 1.

8 Kementerian Lingkungan Hidup, UU. No.23 Tahun 1997, tentang Lingkungan Hidup

${ }_{9}$ Muhtarom Ilyas, Lingkungan Hidup dalam Pandangan Islam, dalam Jurnal Sosial Humaniora Vol.1 No.2, November 2008, 155.
}

${ }^{6}$ Nur Ukhbiyati, Ilmu Pendidikan Islam, (Cet. Ke-3 Bandung: Pustaka Setia, 2005),

328 JURNAL LISAN AL-HAL 


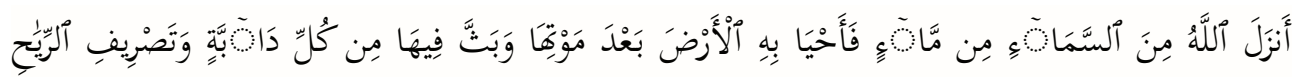

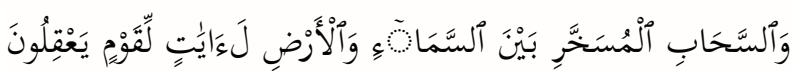

"Sesungguhnya dalam penciptaan langit dan bumi, silih bergantinya malam dan siang, bahtera yang berlayar di laut membawa apa yang berguna bagi manusia, dan apa yang Allah turunkan dari langit berupa air, lalu dengan air itu Dia hidupkan bumi sesudah mati (kering)-nya dan Dia sebarkan di bumi itu segala jenis hewan, dan pengisaran angin dan awan yang dikendalikan antara langit dan bumi; sungguh (terdapat) tandatanda (keesaan dan kebesaran Allah) bagi kaum yang memikirkan"

Ayat tersebut menggambarkan bahwa langit dan bumi sebagai lingkungan yang memberikan dukungan terhadap kehidupan dan kesejahteraan, dalam kehidupan dan tumbuh kembang, bukan terhadap manusia saja, akan tetapi seluruh makhluk hidup seperti hewan dan tumbuhan. Berdasarkan realita, manusia sudah dipastikan tidak akan bisa bertahan hidup tanpa lingkungannya. Lingkungan memberikan segala sesuatu yang manusia butuhkan, seperti air, oksigen, makanan dan minuman.

Dari penjelasan yang sudah dipaparkan, terlihat jelas bahwa lingkungan hidup adalah sumber daya alam yang menopang kehidupan. Jika terjadi kerusakan terhadap lingkungan hidup, maka kehidupan ikut terganggu. seperti di beberapa kasus negeri ini, banyak masyarakat yang terganggu akibat tercemarnya air dan udara yang disebabkan oleh limbah pabrik dan kendaraan bermotor.

\section{Lingkungan Hidup dalam Pendekatan Maqashid Al Syari'ah}

Agama sebagai dasar pedoman hidup manusia tentu sangat mendasari adanya perintah dalam menjaga lingkungan hidupnya. Dalam beragama, sesorang dituntut untuk melaksanakan seluruh ajaran-ajaran agama yang dianutnya. Agama khususnya Islam telah memiliki aturanaturan pokok yang harus dilaksanakan oleh para pengikutnya. Aturanaturan tersebut akan mengantarkan manusia menjaga dan memelihara lingkungan. Di dalam sumber Al Qur'an dijelaskan bahwa Allah menciptakan manusia sebagai khalifah. Kewajiban manusia sebagai khalifah adalah menjaga dan melindungi lingkungan sesuai dengan dasar dan tujuan agamanya. ${ }^{10}$ Islam sendiri telah mengajarkan perlindungan terhadap lima inti yang harus dilindungi dan dijaga sesuai dengan syariat Islam dan dikenal sebagai Maqashid al-Syari'ah.

${ }^{10}$ Ali Yafie, Merintis Fiqih Lingkungan Hidup, (Jakarta: Ufuk Press, 2006), 231.

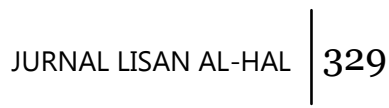


Maqashid al Syari'ah adalah tujuan dasar disyariatkannya hukum Islam. Atau lebih abstraknya dikatakan bahwa Maqashid al Syari'ah adalah konsep untuk mengetahui nilai-nilai dan sasaran yang mengandung syara' yang tersurat dan tersirat dalam al-Qur'an dan hadist. Ada lima dasar yang perlu dijaga oleh manusia, lima dasar tersebut adalah menjaga agama (Hifdz Al-din), jiwa (Hifdz Al-nafs), akal (Hifdzu Al-aql), keturunan (Hifdz Al-nasl) dan harta (Hifdz Al-mal). ${ }^{11}$ Kelima dasar syari'at tersebut mencakup kebutuhan manusia dalam maslahah kebaikan dan kesejahteraan dalam kehidupan di dunia dan akhirat. Berkaitan dengan maslahah, Qardhawi mengaitkan prinsip maslahah dalam konteks ihsan, ibadah dan akhlak. Maslahat yang dimaksud sebagaimana Imam AsSyatiby menjelaskan bahwa maslahat tersebut tidak difahami atas hukum yang statis, akan tetapi memahami hukum dinamis di mana kemaslahatan itu menjadi penunjang keberlangsungan hidup manusia. ${ }^{12}$

Konsep Maqashid al-Syari'ah dirumuskan secara dhorury artinya tanpa memalui pertimbangan rasio mendalam, karena Maqashid alSyari'ah dirumuskan untuk kemaslahatan manusia secara universal. ${ }^{13} \mathrm{Hal}$ ini tentu tidak melepaskan singkronisasi menjaga dan melindungi lingkungan hidup melalui pendekatan lima dasar syari'at karena lingkungan hidup adalah bagian dari kemaslahatan manusia. Dalam konteks menjaga dan memelihara lingkungan hidup, prinsip mashlahah dioperasikan untuk menjaga lingkungan hidup dan pencegahan terhadap kerusakan lingkungan yang diwujudkan dalam bentuk pemeliharaan atas lima tujuan dasar: yaitu memelihara agama, jiwa, akal, nasab, dan properti. Kelima hal tersebut jika dilihat dari kacamata ilmu ekologi merupakan komponen-komponen lingkungan yang eksistensinya mutlak dan penting. ${ }^{14}$

Kaitannya dengan menjaga dan memelihara lingkungan, Yusuf Qardhawi sudah terlebih dahulu mengkolaborasikan antara maslahah alkhams dan lingkungan. Menurut ia, menjaga lingkungan sama halnya dengan menjaga agama. ${ }^{15}$ Artinya dengan menodai, merusak dan apatis

11 Wardani, Islam Rama Lingkungan Dari Eko-Teologi Al Qur'an dan Fiqh Bai'ah, (Banjarmasin: IAIN Antasari Press, 2015), 139.

12 Ibid, 134

13 Ahmad Thohari, Epistimologi Fiqh Lingkungan:Revitalisasi Konsep Masalahah, dalam Jurnal Az Zarqa', Vol. 5, No. 2, Desember 2013, 156.

14 Mudhofir Abdullah, Konservasi Lingkungan dalam Prespektif Ushul Fiqh, dalam Jurnal Millah Edisi Desember 2010, 124.

15 Yusuf Al-Qardhawi, Agama Ramah Lingkungan, (Jakarta: Pustaka Kautsar; 2002), 46.

$330 \mid$ JURNAL LISAN AL-HAL 
terhadap konservasi lingkungan sama halnya mengotori kesucian Agama Islam dan menafikan Islam sebagai agama berarti jika seseorang merusak lingkungan, maka ia tidak mematuhi perintah Agama Islam.

Selanjutnya di bagian lain Qardhawi menyebutkan menjaga lingkungan sama halnya menjaga jiwa, akal, keturunan dan harta. Artinya, jika aspek-aspek jiwa, nasab, akal, dan harta rusak, maka keberadaan manusia di dalam lingkungan menjadi tercemari. Yusuf Qardhawi mengaitkan prinsip maslahat dalam konteks ihsan, ibadah, dan akhlaq. ${ }^{16}$

Dari penjelasan tersebut, dalam pemikiran Yusuf Qardhawi melindungi dan memelihara lingkungan wajib untuk dilaksanakan, karena lingkungan adalah kebutuhan komplek dan universal bagi maslahah kebaikan dan kesejahteraan makhluk hidup khususnya manusia. Dalam hal ini, Ia mengembangkan konsep Maqashid al-Syari'ah, As-Syatibi tentang kemutlakan dalam menjaga dan memelihara dhoruriyah al-khams dari kepunahan.

Berbeda dengan Yusuf Qardhawi yang mengelaborasikan konsep Maqashid al-Syari'ah dengan lingkungan hidup, Musthafa Abu-Sway secara tegas memanifestasikan spirit awal Maqashid al-Syari'ah kedalam spirit modern. Menurut Musthafa Abu Sway, menjaga dan memelihara lingkungan tidak hanya wajib, melainkan mengatakan bahwa menjaga lingkungan merupakan tujuan tertinggi dalam Maqashid al-Syari'ah.

Dengan demikian, para Tokoh atau Ulama sepakat bahwa tujuan Syari'ah tidak lain adalah untuk kemakmuran manusia dan juga untuk kemakmuran lingkungan yang tujuan akhirnya menjadi kesejahteraan manusia. Hal ini didasarakan atas; Pertama, terjaganya kebutuhankebutuhan penting (Maslahah dhorury), tidak mungkin terwujud jika tidak memiliki ketergantungan dengan lingkungan hidup yang baik yang menjadi syarat utama dalam kehidupan. Kedua, manusia selalu mengakami masa perkembang biakan dari waktu ke waktu, sementara lingkungan hidup sampai kapanpun akan ada dan bahkan menjadi salah satu habitat manusia, yaitu bumi. Ketiga, lingkungan alam ini merupakan suatu amanah yang besar dan bukan asset untuk dieksploitasi secara besar-besaran.

Oleh karenanya, seharusnya manusia hanya memanfaatkan lingkungan alam secukupnya saja untuk memenuhi kebutuhannya, dan merawatnya dengan penuh rasa tanggung jawab. Dengan demikian, manusia pantas menyandang predikat sebagai khalifatullâh fi al-'ardh. Maka disinilah konsep Islam atau syari'ah yang sesungguhnya harus

16 Ibid, 46. 
berbeda dengan perspektif kaum reduksionisme seperti yang dikemukakan oleh Francis Bacon dengan argumennya bahwa, tujuan ilmu adalah mampu menguasai dan mengendalikan alam. Sedangkan ilmu pengetahuan bisa dipakai untuk mengubah manusia menjadi majikan atas kepemilikan alam. ${ }^{17}$

Dengan menggunakan pendekatan Maqashid al Syari'ah, semakin menunjukkan bahwa Islam adalah agama yang sangat peduli terhadap lingkungan. Sebagaimana konsep yang sudah dikembangkan oleh Yusuf Qardhawi dan Musthafa Abu Sway yang mampu mendekonstruksi kajiankajian syari'at yang up to date dan relevan.

\section{E. Perilaku Pemeliharaan Lingkungan dalam Islam}

Islam sebagai agama sempurna, tentu menjadi suatu pandangan dalam melaksanakan kehidupan (way of life). Islam telah membuat aturan sebagai pedoman hidup manusia termasuk persoalan pemeliharaan lingkungan. Aturan seperti ini diharapkan manusia mampu berinteraksi dan bersikap bersahabat dengan Lingkungan hidupnya. Lingkungan yang mesti harus kita perhatikan ialah dimulai dari menjaga kebersihan diri, kebersihan rumah dan kebersihan lingkungan di masyarakat yang menjadi tanggung jawab kita semua. ${ }^{18}$ Namun kenyataannya, sedikit sekali diantara masyarakat kita yang mau menghiraukan tentang pentingnya kebersihan lingkungan umum, mulai dari tidak membuang sampah sembarangan, membersihkan kembali sarana dan fasilitas umum setelah digunakan. Oleh karena itu, Islam mengatur bagaimana memelihara lingkungan hidup di sekitar manusia.

Berkaitan dengan memelihara lingkungan, Rasulullah telah menanamkan nilai-nilai pelestarian dan pemeliharaan lingkungan melalui hadits Beliau yang kami rangkum dalam beberapa nilai sebagai mana berikut:

\section{Menjaga Kebersihan Lingkungan}

Menjaga kebersihan merupakan bagian dari iman. Selogan ini sering didengar dan dilihat dan diucapkan sesorang ketika melakukan gerakan bersih. Slogan tersebut bukan berarti tidak memiliki tujuan, akan tetapi memiliki tujuan pokok dalam membawa sesorang pada hakikat manusia. Iman tidak hanya dilihat dari bagaimana seseorang melakukan

\footnotetext{
17 Fritjof Capra, Titik Balik Peradaban, (Yogyakarta: Bentang Pustaka), 53.

18 Safrilshad dan Fitriani, Agama dan Kesadara Menjaga Lingkungan Hidup, dalam Jurnal Subtantia, Vol. 16, No. 1, April 2014, UIN Ar Raniri Banda Aceh, 76.

$332 \mid$ JURNAL LISAN AL-HAL
} 
ritual saja, tapi menjaga kebersihan juga termasuk dari kesempurnaan keimanan seseorang. ${ }^{19}$

\section{Memanfaatkan Tanah Tandus}

Mengelolah tanah tandus atau dalam kajian fiqih lebih dikenal dengan ihyaul wamat adalah bentuk kesadaran seseorang terhadap lingkungannya, artinya tidak membiarkan lingkungan tidak lagi bermanfaat bagi hidup, akan tetapi lingkungan tersebut dapat digali manfaat yang sangat besar. ${ }^{20}$ Semangat ini tergambar oleh penguasaan dan upaya dalam melestarikan, mengelola dan mengkonservasi sebuah kawasan yang tadinya tidak memiliki manfaat sama sekali menjadi lahan produktif karena dijadikan ladang berbagai macam tanaman yang bisa diambil manfaatnya seperti dikonsumsi atau dijual belikan. Allah berfirman dalam QS. Yasin ayat 33:

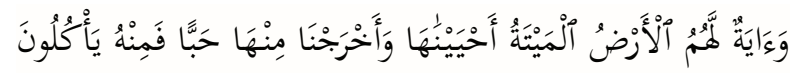

"Dan suatu tanda (kekuasaan Allah yang besar) bagi mereka adalah bumi yang mati. Kami hidupkan bumi itu dan Kami keluarkan dari padanya bijibijian, Maka daripadanya mereka makan"

Ayat ini mengisyaratkan manusia untuk memakmurkan tanahtanah yang mati atau kosong, karena tanah yang Allah ciptakan pasti memiliki manfaat bagi manusia secara khusus dan lingkungan umumnya. ${ }^{21}$ ihya al-mawaat merupakan bentuk perintah kepada kaum muslim untuk senantiasa menjaga dan merawat lahan supaya tidak ada lahan yang terlantar atau tidak bermanfaat dan tidak produktif sehingga dapat tercipta penghijauan, pemanfaatan, pemeliharaan dan penjagaan terhadap lingkungan sekitar.

\section{Penetapan Daerah Konservasi}

Penetapan daerah konservasi atau dalam islam dikenal dengan istilah hima' artinya menetapkan suatu wilayah untuk dilindungi dan tidak digunakan untuk kemaslahatan pribadi. Penetapan konservasi wilayah ini merupakan trik dalam menjaga ekosistem lingkungan sehingga dapat diambil manfaat. ${ }^{22}$ Nabi SAW pernah bersabda tentang penetapan

19 Ulin Ni'am. M, Pelestarian Lingkungan dalam Prespektif Sunnah, dalam Jurnal At Taqaddum, Vol. 6, No. 2 Nopember 2014, 419.

${ }^{20}$ Ali Yafie, Merintis Fiqih Lingkungan Hidup,157.

21 Ulin Ni'am. M, Pelestarian Lingkungan dalam Prespektif Sunnah, 442.

22 Al Mawardi, Imam. Al Ahkam As Sulthaniyyah, (Penerjemah:Fadhil Bahri), (Jakarta :Darul Falah, 2000), 311. 
konservasi lingkungan yang diriwayatkan oleh imam Bukhori: Dari Ibn Abbas berkata: sesungguhnya Rosulullah telah menetapkan Naqi' sebagai daerah konservasi.

Hadis tersebut sudah jelas bahwa Islam menganjurkan melakukan konservasi sebagai media pencegahan kehilangan spesies dan ekosistem yang menggerogoti kesuburan lahan. Oleh karena itu, setiap negara khususnya negara yang terkenal kaya akan alamnya, perlu untuk melakukan konservasi (hima') hayatinya berdasarkan sumber biologinya sehingga dapat melestarikan atau memulihkan representasi kawasan pshsyografis dan biota. ${ }^{23}$ Seperti di Indonesia, setiap kota di Indonesia memiliki wilayah konservasi seperti adanya hutan ditengah kota; contohnya kebun raya bogor, kebun raya Purwosari, pantai-pantai yang ada di malang. Hal ini dilakukan untuk melestarikan dan menjaga satwasatwa yang tergolong spesies langkah dan lingkungan dari berbagai macam yang mengakibatkan kerusakan lingkungan dan gejalah nilai ekonomis.

\section{Penanaman Pohon dan Penghijauhan (Reboisasi)}

Penanaman pohon dan penghijauan (reboisasi) merupakan solusi jangkah panjang untuk melindungi tanah dan mencegah erosi. Reboisasi biasanya dilakukan pada lingkungan yang mengalami kerusakan kemudian mengembalikan fungsi lingkungan tersebut. Dalam pandangan Islam, reboisasi termasuk bentuk amalan sholeh yang tidak terputus pahalanya masuk dalam katergori sedekah karena dengan melakukan reboisasi, bisa menjaga kesetabilan alam yang dapat diambil manfaatnya bagi masyarakat.24

Dalam kaitannya dengan hal ini, Nabi Muhammad pernah bersabda dalam sebuah hadis yang diriwayatkan oleh Imam Bukhori dan Muslim: "Tak ada seorang muslim yang menanam pohon atau menanam tanaman, lalu burung memakannya atau manusia atau hewan, kecuali ia akan mendapatkan sedekah karenanya". Hadis ini tentu memiliki maksud tersendiri dari perintah menanam pohon dan melalukan penghijauhan, yakni tentang adanya manfaat dalam melakukan reboisasi. Ada beberapa manfaat yang dihasilkan dari reboisasi sebagaimana berikut: memproduksi oksigen (02), menerima karbondioksida (CO2), meresapkan

${ }^{23}$ Othman Llewelyn, The Basic for a Discipline of Environmental law in Islam and Ecology R.C. Foltz, F.M. Denny and A.Baharuddin, (Cambridge: Harvard Univ Press, 2003), 216.

${ }^{24}$ Abraham, Pentingnya Penghijauan dan Pelestarian Alam dalam Islam, dalam Buletin Jum'at At Tauhid Edisi II, 2010, 3.

$334 \mid$ JURNAL LISAN AL-HAL 
panas, memfilter debu, menghambat kegaduhan, menjaga keseimbangan tanah, habitat bagi flora-fauna, mengikat air dipori tanah dengan sistem peresapan air melalui celah-celah sempit dan tegangan permukaan sehingga bermanfaat untuk menyimpan cadangan air pada musim hujan dan memberikan air pada musim kemarau. ${ }^{25}$ Dengan demikian, betapa besarnya manfaat melakukan reboisasi. dan jika tidak dilakukan, maka akan terjadi kerusakan hutan yang menyebabkan longsor. Padahal keberadaan hutan sangat berguna bagi keseimbangan hidrologik dan klimatologik termasuk sebagai habitatnya binatang.

\section{Menjaga Keseimbangan Alam}

Sering kali, kerusakan Alam disebabkan oleh sikap boros (tabdzir) dan berlebihan (isyraf). Dengan kecerdasan yang mereka miliki, terkadang manusia lupa adanya keterbatasan sehingga mereka bebas mengeksploitasi lingkungan. Pada akhirnya mereka berlebihan dalam mengelolah sumber daya alam yang ada. Atas dasar itu, kerusakan lingkungan sering kali terjadi atas keserakahan manusia.

Mereka lupa bahwa sifat serakah termasuk akhlat tercela. Secara sadar, manusia menganggap segala sesuatu yang ada di depannya adalah miliknya. Artinya mereka bisa sesuka hati mengambil atau membiarkan. ${ }^{26}$ Masalah tabdzir dan isyraf sudah di singgung Allah SWT dalam QS. Taha ayat 127:

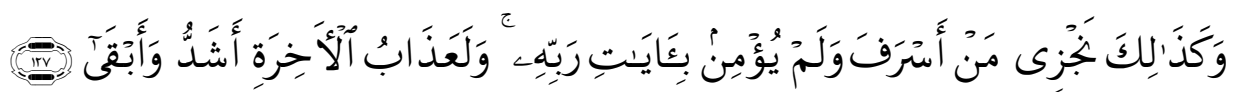

"Dan Demikianlah Kami membalas orang yang melampaui batas dan tidak percaya kepada ayat-ayat Tuhannya. dan Sesungguhnya azab di akhirat itu lebih berat dan lebih kekal"

Secara lebih luas, ayat tersebut mengakomodir pencegahan berlebihan dan boros dalam pemanfaatan lingkungan. Artinya, manusia diperintahkan untuk selalu menjaga keseimbangan alam lingkungannya dengan mengambil manfaat secukupnya. Manusia dan lingkungan adalah simbiosis mutualisme. Manusia butuh alam untuk bertahan hidup dan alam butuh manusia sebagai penjaganya. Manusia dijuluki sebagai Khalifah Allah di muka bumi, mereka diberikan potensi untuk memelihara dan mengatur alam ini secara kreatif, produktif, konstruktif, dan

25 Ulin Ni'am. M, Pelestarian Lingkungan dalam Prespektif Sunnah, 424.

26 Dudung A. Rohman, Israf Dan Tabdzir: Konsepsi Etika-Religius Dalam Al Qur'an Dan Perspektif Materialisme Konsumerisme, dalam Jurnal Mimbar, Vol. 21. No. 1 Januari 2005, 80 . 
humanis. ${ }^{27}$ Manusia selayaknya berperilaku sesuai tuntunan moral yang baik. Tanpa adanya tuntunan moral, kita dapat membayangkan bagaimana hubungan-hubungan tersebut pasti mengalami kekacauan dan hanya akan memberikan kegaduhan dalam kehidupan umat manusia.

\section{F. Hubungan Pendidikan Islam dan Lingkungan Hidup}

Realitas sosial menunjukkan "pendidikan" memiliki hubungan erat dengan lingkungan, mengingat manusia tidak bisa terpisahkan dengan lingkungannya. Sejak lahir manusia berinteraksi dan membutuhkan lingkungan untuk pertumbuhan dan kesejahteraan hidup, bahkan seluruh prilaku manusia terkonstruk oleh lingkungan. Oleh karena itu, pendidikan dan lingkungan saling berhubungan, karena keduanya membantuh manusia dalam menjalankan tugasnya.

Sebelum penulis membahas hubungan pendidikan agama Islam dengan lingkungan, penulis akan terlebih dahulu membahas sedikit tentang tugas manusia. Menurut penciptaannya, manusia memiliki dua tugas pokok di bumi; pertama, sebagai 'abid (yang menyembah) dan khalifah. Manusia sebagai 'abid adalah hambah yang memiliki Tuhan untuk disembah, tugas pertama ini adanya hubungan manusia dengan Allah Swt. Sedangkan tugas yang kedua, manusia sebagai khalifah, artinya manusia sebagai wakil Allah Swt. di bumi yang memiliki tugas menjaga dan memakmurkan bumi. Hal ini adanya keterkaitan manusia dengan sesamanya dan lingkungan hidupnya. Urwati Aziz menyebut tiga hubungan tersebut membentuk segitiga sama sisi yang dikenal dengan triangle arrangement $: 28$

Gambar.

Triangle Arrangement

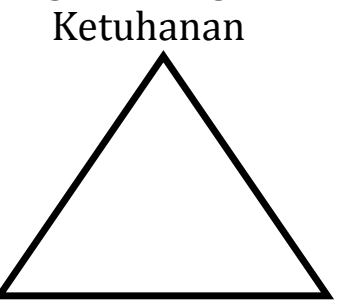

Kemanusiaan Ekologis

Diletakkan hubungan ketuhanan diatas, karna Tuhan adalah

27 Ulin Ni'am. M, Pelestarian Lingkungan dalam Prespektif Sunnah, 426.

28 Erwati Aziz, Op.Cit.., 58

$336 \mid$ JURNAL LISAN AL-HAL 
pencipta alam semesta dan yang berhak memiliki alam semesta ini. Ia maha Raja yang memiliki kemutlakan dalam penciptaan dan penghancuran alam serta wajib disembah oleh. Sedangkan kemanusiaan dan ekologis adalah subsistem dari suprasistem ciptaan Tuhan. ${ }^{29}$ Dari setiap hubungan tersebut, penulis mencoba menguraihkan ketiga dimensi sebagai berikut:

1. Hablum Min Allah. Manusia merupakan makhluk ciptaan Allah SWT. Manusia diciptakan Allah SWT, sebagai hambah ('Abid) dan wakil (Khalifah) di bumi. Hubungan manusia dengan Allah adalah tergolong posisi manusia sebagai hambah ('abid). Sebagai hambah ('abid), manusia diharuskan tunduk dan patuh terhadap Allah SWT. ${ }^{30}$ Artinya seluruh jiwa dan aktifitas manusia harus sesuai dengan izin dan aturan dari Allah SWT. Posisi manusia sebagai hambah ('abid).

2. Hablum Min Annas. Berbicara tentang Hablum minannas berarti berbicara tentang manusia sebagai makhluk sosial. Arisoteles mengatakan bahwa manusia adalah makhluk zoon politicon, maksudnya manusia merupakan makhluk yang ingin hidup berkelompok dengan sesamanya atau dengan kata lain makhluk yang senang bermasyarakat. Karena dengan sifat senang hidup berkelompok, maka manusia dapat dikatakan sebagai makhluk sosial. ${ }^{31}$

3. Hablum Min Al alam. Hubungan manusia dengan alam (lingkungan hidup) bagaikan hubungan ikan dengan air. Artinya air memberikan ikan kehidupan, begitupun juga dengan alam yang memberi kehidupan bagi manusia. Meskipun sama-sama berada dalam instruktur garis horizontal dengan hubungan manusia dengan manusia, namun yang dimaksud dengan hubungan manusia dengan alam adalah hubungan ekologis sebagai upaya manusia hidup berdampingan dengan alam secara serasi dan harmonis.

\section{G. Simpulan}

Dari hasil pembahasan artikel di atas penulis dapat menyimpulkan bahwa betapa pentingnya peran pendidikan agama Islam dalam upaya mengatur dan memelihara keseimbangan lingkungan hidup. Disadari atau tidak, kita telah merasakan dampak dari permasalahan lingkungan yang diakibatkan oleh keserakahan manusia dalam mengeksploitasi sumber

${ }^{29}$ Ibid, 59

30 Burhanuddin Yusuf, Manusia dan Amanahnya Kajian Teologis Berwawasan Lingkungan, dalam Jurnal Aqidah-Ta Vol. II, No. 2, Tahun 2016, 125.

31 Zulkarnain Dali, Hubungan Antara Manusia, Masyarakat, dan Budaya dalam Prespektif Islam, dalam Jurnal Nuansa, Vol. IX, No. 1 Tahun 2016, 47. 
daya alam yang ada di bumi ini. Sehingga dari situ dapat menyebabkan berbagai bencana alam, seperti halnya banjir, tanah longsor, dan lain-lain. Padahal secara fitrahnya, manusia diciptakan oleh Allah di muka bumi ini tugasnya hanya sebagai pemelihara keseimbangan alam lingkungan ini. Dengan demikian, diharapkan melalui penanaman pendidikan agama Islam berwawasan lingkungan, agar dapat melatih pribadi manusia menjadi hamba Allah yang benar-benar menjadi khalifah fil ardi, bukan hamba yang berbuat mafsadat.

\section{DAFTAR PUSTAKA}

A. Rohman, Dudung. Israf dan Tabdzir: Konsepsi Etika-Religius Dalam Al Qur'an Dan Perspektif Materialisme Konsumerisme, dalam Jurnal Mimbar, Vol. 21. No. 1 Januari 2005.

Abdullah, Mudhofir. Konservasi Lingkungan dalam Prespektif Ushul Fiqh, dalam Jurnal Millah Edisi Desember 2010.

Abraham. Pentingnya Penghijauan dan Pelestarian Alam dalam Islam, dalam Buletin Jum'at At Tauhid Edisi II, 2010.

Ahmadi dan Ukhbiyati, Nur. Ilmu Pendidikan, Jakarta: Rineka Cipta, 2007.

Ahmadi. 2004. Psikologi Pendidikan, Jakarta: Rineka Cipta.

Al Mawardi, Imam. Al Ahkam As Sulthaniyyah. (Penerjemah:Fadhil Bahri), Jakarta :Darul Falah, 2000.

Al-Qardhawi, Yusuf. Agama Ramah Lingkungan. Jakarta: Pustaka Kautsar, 2002.

Dali, Zulkarnain. Hubungan Antara Manusia, Masyarakat, dan Budaya dalam Prespektif Islam, dalam Jurnal Nuansa, Vol. IX, No. 1 Tahun 2016.

Daradjat, Zakiah. Ilmu Pendidikan Islam, Cet, ke 3, Jakarta: Bumi Aksara, 2008.

Erwati, Aziz. Pelestarian Lingkungan Melalui Pendidikan Agama Islam, Yogyakarta: Pustaka Belajar, 2013

Hamza, Syukri. Pendidikan Lingkungan Hidup Sekelumit Wawasan Pengantar, Bandung:Revika Aditama, 2013.

Ilyas, Muhtarom. Lingkungan Hidup dalam Pandangan Islam, dalam Jurnal Sosial Humaniora Vol.1 No.2, November 2008.

Kementerian Lingkungan Hidup, UU. No.23 Tahun 1997, tentang Lingkungan Hidup.

Kutanegara, Pande Made dkk. Membangun Masyarakat Indonesia Peduli Lingkungan. Yogyakarta: UGM Press, 2014.

338 JURNAL LISAN AL-HAL 
Llewelyn, Othman. The Basic for a Discipline of Environmental law in Islam and Ecology R.C. Foltz, F.M. Denny and A.Baharuddin.(Cambridge: Harvard Univ Press, 2003.

Ni'am. Ulin. Pelestarian Lingkungan dalam Prespektif Sunnah, dalam Jurnal At Taqaddum, Vol. 6, No. 2 Nopember 2014.

Safrilshad dan Fitriani. Agama dan Kesadara Menjaga Lingkungan Hidup, dalam Jurnal Subtantia, Vol. 16, No. 1, April, UIN Ar Raniri Banda Aceh, 2014.

Thohari, Ahmad. Epistimologi Fiqh Lingkungan: Revitalisasi Konsep Masalahah, dalam Jurnal Az Zarqa', Vol. 5, No. 2, Desember 2013.

Ukhbiyati, Nur. Ilmu Pendidikan Islam, Cet. Ke-3 Bandung: Pustaka Setia, 2005.

Wardani.. Islam Ramah Lingkungan Dari eko-Teologi Al Qur'an dan Fiqh Bai'ah, Banjarmasin: IAIN Antasari Press, 2015.

Yafie, Ali. Merintis Fiqih Lingkungan Hidup, Jakarta: Ufuk Press, 2006.

Yusuf, Burhanuddin. Manusia dan Amanahnya Kajian Teologis Berwawasan Lingkungan, dalam Jurnal Aqidah-Ta Vol. II, No. 2, Tahun 2016. 
"PAI Berwawasan Lingkungan Hidup"

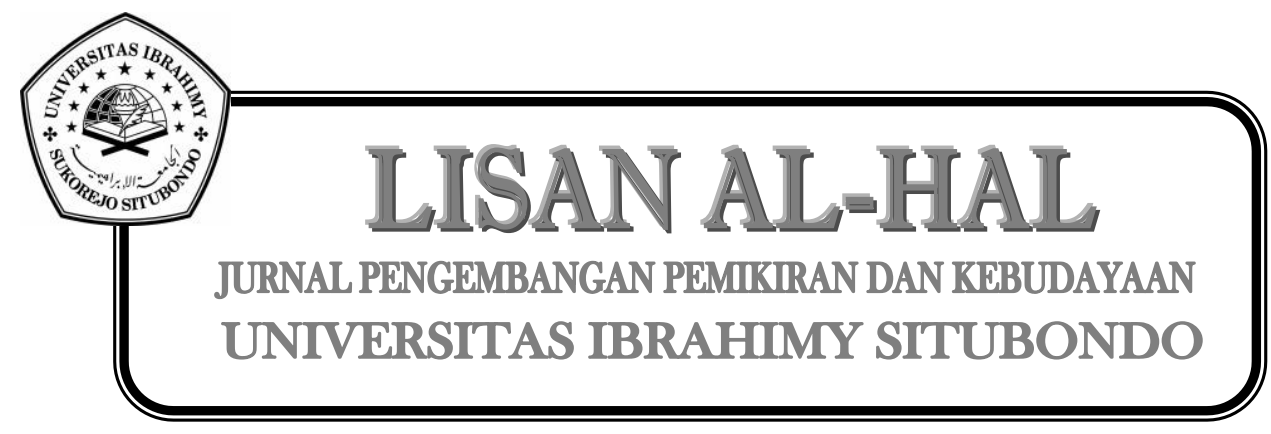

340 JURNAL LISAN AL-HAL 